\title{
Valuation of medieval churches; taking account of laypersons’ views
}

\author{
Tineke van der Schoor ${ }^{1}$, Ezequiel Colmenero-Acevedo², Maarten Vieveen ${ }^{1}$
}

${ }^{1}$ Kenniscentrum NoorderRuimte, Hanze University of Applied Sciences, (HUAS), Groningen, The Netherlands. c.van.der.schoor@pl.hanze.nl; m.c.vieveen@pl.hanze.nl

${ }^{2}$ Scottish Centre for Conservation Studies, The University of Edinburgh, (UoE), Edinburgh, United Kingdom. eze.colmenero@ed.ac.uk

\begin{abstract}
In this paper we investigate laypersons' valuation of historic buildings, their experiences of thermal comfort in those buildings and contrast this with their views on the appropriateness of energy efficiency measures. This paper presents four case studies of medieval churches in Groningen, Netherlands. Valuation studies is used to investigate the values that are attached to historic buildings by various stakeholders. We apply the 'heritage as a spatial vector' approach, to position heritage in relation to developments in society and the landscape. Our theoretical contribution lies in the combination of heritage approaches and valuation studies. We conclude that for a more balanced assessment of historic buildings, laypersons' valuations should be further integrated in heritage studies.
\end{abstract}

Keywords - medieval churches; energy efficiency; laypersons' valuation; heritage as spatial vector; Netherlands

\section{INTRODUCTION}

The quest for preserving historic buildings does not always align with the ambition to promote sustainability in the built environment. In this paper, we investigate laypersons' values regarding historic buildings, as well as their views on energy efficiency and retrofit measures. We argue that their perspective could enrich architectural heritage policies and decisions. Our cases are set in the north of the Netherlands, in the province of Groningen, which is a rural area renowned for its medieval churches. Many of these churches are under the protection of the Stichting Oude Groninger Kerken (SOGK), a foundation dedicated to historic churches in Groningen. Since 1969 SOGK has acquired 85 churches, and takes care of their conservation, renovation, and regular maintenance. Importantly, for the majority of church buildings local voluntary committees take care of the daily use and exploitation of their village church. The perspective of laypersons is thus very relevant for the management of the church.

Architecture is a cultural product and as such, all buildings are influenced by the culture and time of their creation. The inclination to assign value to the past and the wish to preserve historic artefacts "has a very long history and may arguably (..) be an inherent human trait” [1]. Walter [2] argues that conservation starts with the identification, description and prioritisation of values. The assessment of 
values of historic buildings and urban areas is traditionally considered to be a task for experts, such as building and architecture historians. De la Torre [3] recognizes the mutability of values and the complex process to identify them: "The values of heritage are not simply 'found' and fixed and unchanging, as was traditionally theorized in the conservation field (i.e., the notion of heritage values being intrinsic)." Because heritage values are complex, diverse and change over time, they have to be defined on a caseby-case basis. Fredheim \& Khalaf [4] show the daunting variety of value typologies that have been developed in the past decades, and propose a three step approach to clearly identify the features, aspects and qualifiers of value in heritage.

Opposite to the experts view presented by Walter [2], Helgesson and Muniesa [5] outline valuation as a social practice present in several disciplines and human activities, which can refer to the assessment, provision or production of value. Moreover, Vatin [6] argues that valorising, or improving value, is an integral part of the practice of valuation. Therefore, the role of conservation is to "preserve and enhance values". Heuts and Mol [7] suggest that stakeholders use specific sets of valuation criteria, which they call 'registers', related to professional background or interest.

On a fundamental level, three perspectives on heritage management are defined that consecutively influenced heritage discourse in the $20^{\text {th }}$ century. These heritage paradigms [1] or heritage approaches [8-10] "frame heritage issues in their own way, resulting in different ways of formulating solutions to tackle current spatial challenges and, as a consequence, different types of planning and management strategies” [9].

The Preservation paradigm or heritage-as-a-spatial-sector-approach, which was developed from the 1940s onwards, aims to keep heritage as it is or how we think it was into the future [1,9]. Within this approach "Counteracting forces must be organised to prevent possible loss, to save what is irreplaceable in historical terms." [8].

In the 1970s, policy makers argued for "a more systematic and supportive environment for a wider and more dynamic scope of heritage conservation" [9]. This approach was more broadly adopted in the 1990s, when experts in the field of urban planning and design experienced stagnation in spatial development, due to the 'culture of loss' which dominated heritage management. Since developments also contributed to finance conservation, experts from different fields started experimenting with the idea of a 'culture of profit' [8]. This Conservation paradigm [1] or Heritage-as-a-spatial-factorapproach [9] placed heritage "in the framework of dynamic planning and decision-making processes as part of area developments." [9] This approach had a large impact on the practice of heritage valuation: it widened from a mono-disciplinary perspective (heritage experts) towards a multi-disciplinary perspective which allowed professionals involved in urban planning and design to take part in the process. As a result, new values were introduced and priorities in weighting values changed, allowing the improvement of heritage towards present needs.

Janssen et al. expect that "the paradigm shift [...] from logical positivism (leading to objectified assessment and selection and a rational approach to heritage) towards social constructivism (with scope 
for emotion and engagement, different cultural perspectives and forms of appropriation and appreciation) will become even more important." [8] This is in line with this more fundamental paradigm shift, Janssen et al. [9] identified the Heritage-as-a-spatial-vector-approach, which is comparable with Ashworths' [1] Heritage paradigm. This approach does not focus on traditional heritage values nor on discussing the importance to improve the current use which benefits heritage conservation. Instead, Ashworth [1] states:

"Structures and sites are seen as vehicles for the transmission of historicity, contributing to many contemporary social, political and economic needs. It is the fashioning of some representation of a past in the present from selected relics, memories and histories. The purpose is thus not to preserve anything from the past but to use the past in the present: the use determines and, in that sense, creates the resource rather than use being a subsequent action for something already preserved."

This approach takes on board how the meaning of heritage inspires new developments [10] This is in line with Fouseki and Cassar [11], who argue that it is important to understand how people feel and behave towards their built environment and how they value their buildings and the impact of energy efficiency improvements. As a result, the traditional hierarchy of experts and non-experts fades away: plans emerge pre-eminently from the stories and memories (and initiative) of local inhabitants in combination with the knowledge of experts.” [9] Heritage values are widely considered the guiding principle that determine the relevance of historical buildings for conservation; ironically is not very clear or under consensus how to use those values in the conservation planning process and decision-making [12]. The application of values seems to vary per region and to change with each new policy. Their identification is a process widely homogenized, but not unified, their specific use is not under consensus at all.

"Building conservation is distinctly different from the physical processes of repair and adaptation. It is an attitude of mind, a philosophical approach, that seeks first to understand what people value about a historic building or place beyond its practical utility and then to use that understanding to ensure that any work undertaken does as little harm as possible to the characteristics that hold or express those values." [13]

Although it is increasingly recognized that actors may attach different meanings, values and interests to heritage, it remains unclear how these different views can be taken up in the general valuation process. We argue that sustaining historic churches should be positioned in a wider social context, therefore this paper investigates valuation of historic buildings by laypersons, i.e. those without a background in architectural history. We consider that a laypersons valuation not only includes classic heritage values, but also community values, utility values, such as user experience, usability, thermal comfort and energy efficiency. Our contribution to the literature is twofold; firstly, our investigation sheds light on the values that laypersons attach to historical buildings and how this translates to their attitudes towards retrofit measures, secondly, we underpin the need to take up laypersons' values in the traditional valuation process. 
To investigate this, we carried out four case studies on medieval churches owned by SOGK. In the following, we briefly outline our methods first, then describe the case studies and discuss identified valuation processes and strategies. Finally, we draw conclusions finding that for a more balanced approach, laypersons' valuations of historic buildings should be further integrated in heritage studies. Furthermore, we find that the integration of laypersons' values fits very well with the approach of heritage as a vector for development.

\section{METHODS AND MATERIALS}

For this paper, we carried out four case studies [14] on medieval churches owned by the SOGK in Groningen: Nieuw Scheemda, Leegkerk, Lettelbert, and Obergum. We collected empirical data by site visits, archival research, a questionnaire and semi-structured interviews with members of the local church committee [15]. Our respondents are volunteers, who are personally involved in the day-to-day use of the church building. In our study, we distinguished three valuation aspects: a valuation of the church building itself, a valuation of the experienced thermal comfort in the church, and an evaluation of energy retrofit proposals.

Before the interview, each respondent filled out a questionnaire about the building regarding its thermal comfort, interventions to improve its energy performance and how he or she valued it personally.

The starting point for our interview was letting respondents express the importance of a selection of sociocultural values. The selection was based on the literature $[2,11][3,13]$ and included Age value; Architectural and artistic value; Emotional value; Historic value; Religious value; Political value; Educational value; Community value; and Non-use economical value. However, we kept an open mind as to user values that came up during the interviews and site visits. During the second part of the interview, respondents discussed the experienced thermal comfort during the day-to-day-use. Finally, we used photo-elicitation for the evaluation of energy retrofit proposals.

We held a group interview with each local church committee; in total 10 respondents took part in the study. The age range of respondents is between 47 and 74, professions include teachers (4), painter, (physio)therapist (2), psychologist, supermarket employee and nurse (Table 1). Five respondents are pensioners. Interviews were transcribed and analysed according to usual procedures in qualitative research $[15,16]$.

Table 1: Respondents' characteristics

\begin{tabular}{ccccccc} 
Location & $\begin{array}{c}\text { Respon } \\
\text { dent }\end{array}$ & $\mathbf{m} / \mathbf{f}$ & Age & Profession & Relation to church & Type of interview \\
\hline $\begin{array}{c}\text { Nieuw } \\
\text { Scheemda }\end{array}$ & $1^{*}$ & $\mathrm{M}$ & 62 & $\begin{array}{c}\text { Supermarket } \\
\text { employee }\end{array}$ & Sacristan & Group interview
\end{tabular}




\begin{tabular}{|c|c|c|c|c|c|c|}
\hline $\begin{array}{c}\text { Nieuw } \\
\text { Scheemda }\end{array}$ & 2 & $\mathrm{~F}$ & 60 & Nurse & Partner of sacristan & Group interview \\
\hline $\begin{array}{c}\text { Nieuw } \\
\text { Scheemda }\end{array}$ & 3 & $\mathrm{~F}$ & 47 & $\begin{array}{c}\text { Teacher MBO Social } \\
\text { sciences/ Dutch }\end{array}$ & committee member & Group interview \\
\hline Leegkerk & $4^{*}$ & M & 64 & $\begin{array}{c}\text { Pensioner, former } \\
\text { teacher }\end{array}$ & $\begin{array}{c}\text { voluntary personnel } \\
\text { Bijzondere Locaties } \\
\text { Groningen BV }\end{array}$ & Individual interview \\
\hline Leegkerk & 5 & $\mathrm{~F}$ & 67 & $\begin{array}{c}\text { Pensioner, former } \\
\text { physiotherapist }\end{array}$ & $\begin{array}{c}\text { voluntary personnel } \\
\text { Bijzondere Locaties } \\
\text { Groningen BV }\end{array}$ & Individual interview \\
\hline Lettelbert & $6^{*}$ & M & 58 & $\begin{array}{l}\text { Painter, teacher of } \\
\text { icon-painting classes }\end{array}$ & Teacher & Group interview \\
\hline Lettelbert & 7 & $\mathrm{~F}$ & 53 & $\begin{array}{c}\text { Psychologist and } \\
\text { filmmaker } \\
\end{array}$ & Partner of resp. & Group interview \\
\hline Lettelbert & 8 & $\mathrm{~F}$ & 74 & $\begin{array}{c}\text { Pensioner, former } \\
\text { teacher }\end{array}$ & $\begin{array}{c}\text { Participant of } \\
\text { painting workshop }\end{array}$ & Group interview \\
\hline Lettelbert & 9 & $\mathrm{~F}$ & 62 & $\begin{array}{c}\text { Pensioner, former } \\
\text { teacher }\end{array}$ & $\begin{array}{c}\text { Participant of } \\
\text { painting workshop }\end{array}$ & Group interview \\
\hline Obergum & $10^{*}$ & M & 64 & $\begin{array}{c}\text { Pensioner, former } \\
\text { therapist }\end{array}$ & $\begin{array}{c}\text { chairman of local } \\
\text { committee }\end{array}$ & Individual interview \\
\hline
\end{tabular}

\section{CASE STUDY BUILDINGS}

The case study buildings were selected from the SOGK-portfolio based on the availability of data and respondents. In the text below we describe the case study buildings. Furthermore, we have collected background information regarding locations, buildings dimensions, daily use, energy systems and energy data (Table 2). Data about yearly energy use was provided by the local committees during a related research project (2011-2013). Data about yearly energy use of Leegkerks' church, provided by SOGK, is based on the period after the renovation process in 2013 (May 2012-May 2017). In the following sections we present the four case study buildings. 


\subsection{NIEUW SCHEEMDA}

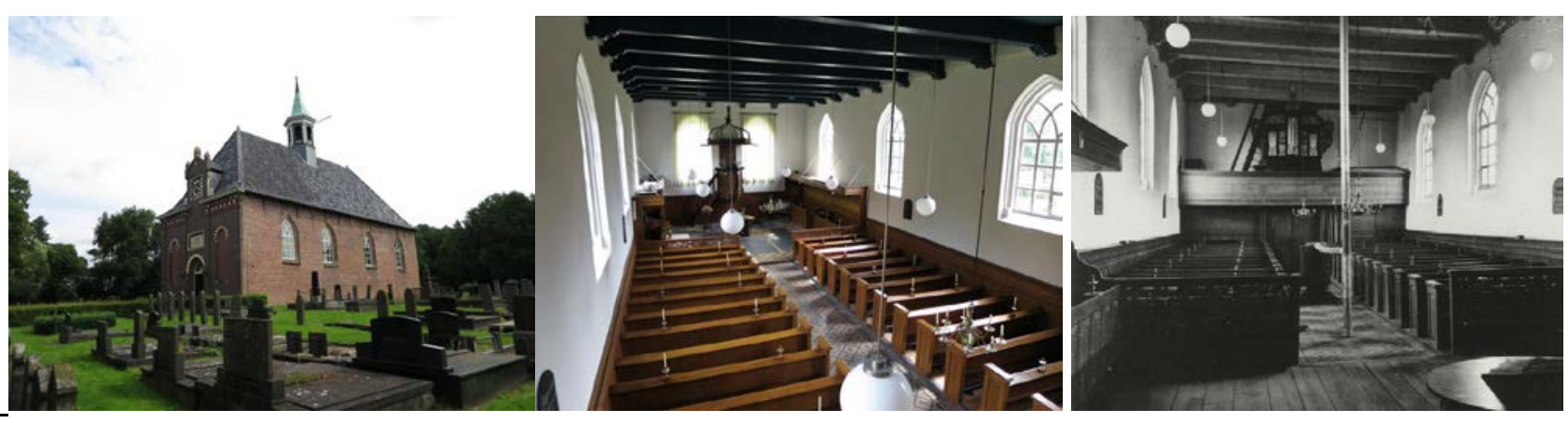

Figure 1: Nieuw Scheemda a) exterior; b) current interior; c) old interior (organ, heating stove) [17]

Location and history: Nieuw Scheemda is a small village (about 140 inhabitants) and is part of the municipality of Oldambt in the province of Groningen and evolved in 1659 as a parochial separation from the village Scheemda. The land of the village is part of a polder that was created at the end of the 16th Century by reclaiming land from the bay called Dollard.

The Late Gothic Reformed Church of Nieuw Scheemda is situated at the Hamrikkerweg 17 (coordinates: $53^{\circ} 12^{\prime} 36.29^{\prime \prime} \mathrm{N}, 6^{\circ} 56^{\prime} 33.22^{\prime \prime} \mathrm{E}$ ). The church was built in 1661, as it is documented in the entrance of the church. The organ in the church is extremely relevant; it is considered one of the six organs practically unaltered that were made by the renowned organ builder Arp Schnitger that survive in the province of Groningen. The Nieuw Scheemda organ itself dates to 1695 but was given to the church in 1698 (figure 1c). The organ was partially rebuilt in 1802 by Heinrich Hermann Freytag. It is said that it is the smallest organ ever built by Schnitger. On 2 November 1971, the church and interior that is attached to it were listed for its national importance and registered as monument 33078.

The façade of the church was replaced and modernized in 1908 with two big windows that had the intention to imitate the typical Dutch countryside houses. In 1981, the ownership transferred to the SOGK which started a maintenance and adaptive reuse project. During the renovation process the energy systems were renewed.

Building and interior: Nieuw Scheemda's church is a medium-sized church (heated surface 148 $\mathrm{m}^{2}$; heated volume $976 \mathrm{~m}^{3}$ ); the apse is located towards the East, the narthex and entrance towards the West (figure 1a). All the exterior (uninsulated) walls are brick masonry while the interior walls are plastered. There are four large windows with equilateral arches on each North and South walls, together with two windows of smaller size on the apse wall and two blind windows of the same kind on the narthex wall. All windows are provided with single glass. The hood construction above the attic consists of an uninsulated roof with roof tiles. 
In the interior, it is a simple church, highly symmetrical. The floor starts in a corridor of decorated clay and two wooden platforms that support the pews (figure 1b). The pews are placed on an (uninsulated) tile floor, the alter section floor is formed by clay and antique gravestones. The wooden ceiling between the church hall and attic is uninsulated.

Daily use: Concerts form the main use of the church, which take place about four times a year. On average these concerts have a duration of two hours and attract about 50 visitors. Besides concerts, a religious service takes place ones a year (Christmas) and has a duration of about 1,5 hours and attracts about 70 visitors.

Energy systems and energy use: The average electricity use (954 kWh) is the result of diverse small devices and artificial lighting during activities. The average use of natural gas $\left(2.069 \mathrm{~m}^{3}\right)$ is the result of the heating system. A gas boiler in the attic provides warmth (via uninsulated pipes) for the convectors in the lobby and for the convectors and heated pipework underneath pews in the church hall. The basic temperature (no activities) is during winter months set on $10^{\circ} \mathrm{C}$ and during activities increased to $18^{\circ} \mathrm{C}$. The pre-heating time is twelve hours in advance.

\subsection{LEEGKERK.}

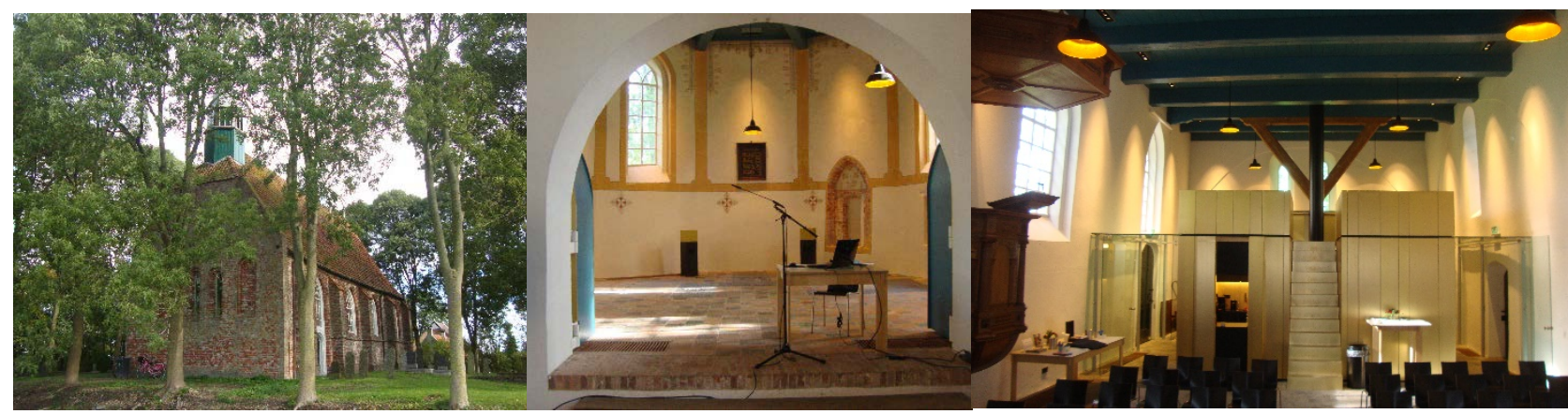

Figure 2: Leegkerk a) exterior; b) apse with storage doors; c) nave with glass draught lobbies. [18]

Location and history: Leegkerk is a hamlet within the municipality of Groningen, the church has only two neighbour houses and the rest of the houses in the hamlet are sparse farms. Leegkerk is bastion of 'Legakerke' ('low lying church') which is mentioned in 1385 and refers to the low-lying area in which the church was built in contract to the higher-lying area where the village of Hoogkerk is situated.

The church is situated at the Leegeweg 38 (coordinates: $53^{\circ} 13^{\prime} 47.6^{\prime \prime} \mathrm{N}, 6^{\circ} 29^{\prime} 25.34^{\prime \prime} \mathrm{E}$ ). The original church was built during the Romanic period in the 13th Century as a Romano-Gothic church. The South wall, the gallery and the tower are from the 18th Century. Especially relevant to its Gothic past are the piscina on the south wall and the small arched windows. On 9 November 1971, the church and interior that is attached to it were listed for its national importance and registered as monument 18755. 
The south wall was destroyed in a battle in 1514 when the Duke of Saxony invaded Westerlauwers Friesland (current province of Fryslân) and rebuilt about 1620. During the first half of the $20^{\text {th }}$ century the church lost many members and maintenance was reduced to a minimum. In 1970 SOGK became owner of the church, which was in a very bad condition. In the following years, the church exterior was totally renovated (figure 2a), in this period the historic heating stove in the centre of the nave was removed. In 2012, the interior was modernised based on a design of AWG architects.

Building and interior: Leegkerks' church is a middle-sized church (heated surface $177 \mathrm{~m}^{2}$; heated volume $1108 \mathrm{~m}^{3}$ ); the apse is located towards the East. All the exterior (uninsulated) walls are made with the typical brickworks from the region. The entire exterior is the brick is uncovered, while the interior is plaster from the recent renovation. There are seven large windows with equilateral arches on the North, East and South wall. The West wall contains five smaller windows without arches. All windows are provided with single glass. The hood construction above the attic consists of a uninsulated roof with roof tiles.

After the modernisation of Leegkerks' church the interior was removed except for the historic pulpit. Paintings were restored and the tile floor was replaced on top of a concrete after a floor heating system was installed. (with some insulation under the heating system) Nowadays the apse and nave of the church can be separated by one meter thick (gold painted) doors which are at the same time act as storage room for chairs and tables. (figure 2b) In the centre of the nave a (gold painted) service box has been added which contains sanitaria and a pantry and on top space was created for activities. The North and South entrances are provided with glass walls and ceiling which makes them function as draught lobby. (figure 2c) The wooden ceiling between the church hall and attic is insulated.

Daily use: Until 2012 the day-to-day use was organised by a local committee. After the modernisation of the interior the church day-to-day use is managed by Bijzondere Locaties Groningen $\mathrm{BV}$, an professional organization that rents historic buildings in the province of Groningen for a variety of activities. The church is very often for diverse activities, such as concerts, choir rehearsals, parties, receptions, special services (marriage) and visiting. The average duration of activities is about 2 hours and attracts (on average) about 20 up to 90 visitors.

Energy systems and energy use: The average electricity use (2.803 kWh) is the result of artificial lighting and diverse devices which are temporary placed according to the demands of the activities which takes place. The average use of natural gas $\left(3.727 \mathrm{~m}^{3}\right)$ is the result of the heating system. A gas boiler in the attic provides warmth (via uninsulated pipes) for the floor heating system and to the convectors in the apse. The basic temperature (no activities) is during winter months set on $10^{\circ} \mathrm{C}$ and during activities increased to $20^{\circ} \mathrm{C}$. The pre-heating time is at least four hours in advance. 


\subsection{LETTELBERT}
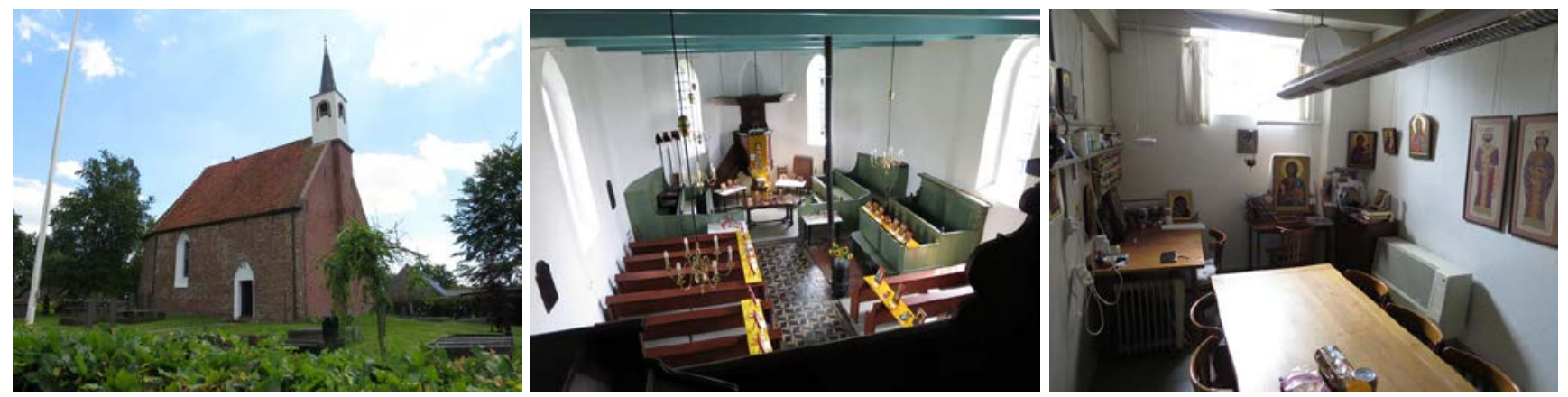

Figure 3: Lettelbert a) exterior; b) interior and historic stove; c) icon painting classroom. [17]

Location and history: Lettelbert is a village (about 200 inhabitants) that belongs to the municipality of Leek. It is a small agricultural village of origin and was born in the Middle Ages on a sand ridge.

The Romanic church of Lettelbert dates back from the 13th Century and is situated at the Hoofdstraat 16 (coordinates: $53^{\circ} 11^{\prime} 19.8^{\prime \prime} \mathrm{N}, 6^{\circ} 24^{\prime} 20.5^{\prime \prime} \mathrm{E}$ ). When in the 17th Century the church became Protestant, the old altar was placed in the entrance so the people would step over the Catholic altar. On 23 May 1973, church and interior were listed for its national importance and registered as monument 23979.

In 1977, the ownership transferred to the SOGK which started a maintenance and conservation project. During the restoration of the church in 1985 the altar was returned to its original place and the energy system was extended.

Building and interior: The building is a small church (heated surface $95 \mathrm{~m}^{2}$; heated volume 497 $\mathrm{m}^{3}$ ) with an east-west orientation (apse East, narthex West). It has only one door, in the North façade. The West façade is modern; it was rebuilt at the end of the 19th Century. It has a small tower and the apse is rounded. All windows are provided with single glass, and some windows have been bricked up. The exterior walls are fully (uninsulated) brickworks, the hood construction above the attic consists of an uninsulated roof with roof tiles (figure 3a).

The interior walls are generally plastered, the wooden ceiling is uninsulated and the pews are more compact. The (uninsulated) floor is clay in the entrance and gravestones in the altar area. A pulpit dominates the apse (figure 3b).

Daily use: Lettelberts' church is used as an centre for icon painting (figure 3c), workshops take place about three times a year. Besides workshops diverse other activities and religious services take place occasionally. The duration of activities differ between two to four hours. Although numbers differ, about 15 students participate in the icon painting workshops. 
Energy systems and energy use: The average electricity use (678 kWh) is the result of diverse small devices, artificial lighting during activities and electric radiators used for heating the icon painting classrooms. The average use of natural gas $\left(785 \mathrm{~m}^{3}\right)$ is the result of the historic gas stove in the centre of the nave that provides warmth. During winter the church hall is not heated, the temperature during users' activities is $18{ }^{\circ} \mathrm{C}$. The pre-heating time of the electric radiators is one hour in advance, and the pre-heating time of the historic gas stove in the church is one hour in advance.

\subsection{OBERGUM}

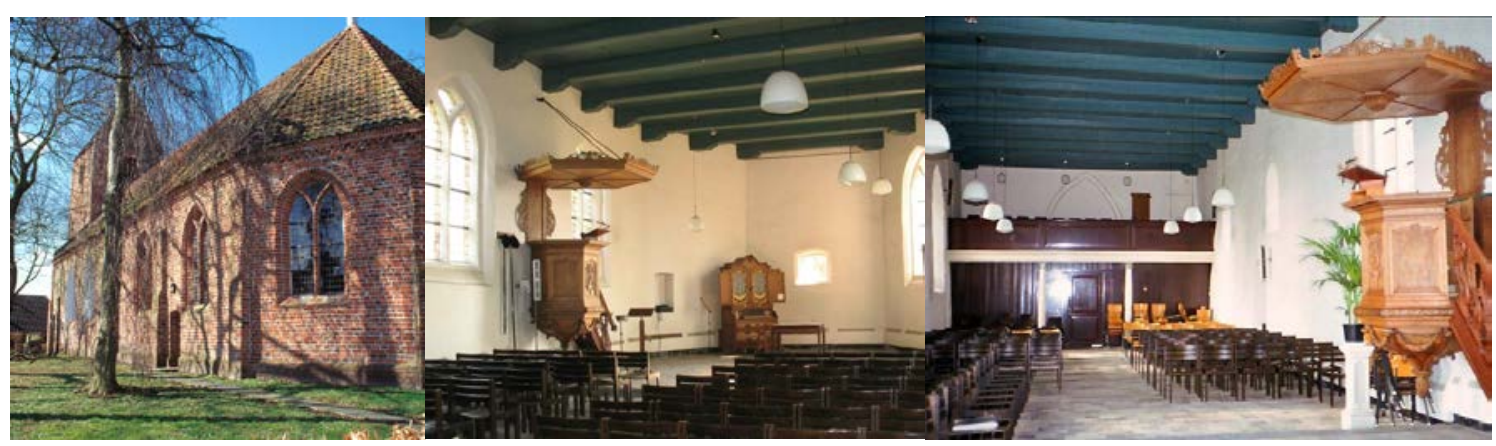

Figure 4: Obergum a) exterior; 2) interior with organ in apse; 3) interior towards the east. [19]

Location and history: Obergum and its twin village Winsum belong to the municipality of Winsum, formed in 1811. Since the middle ages the villages are connected by a bridge over the Winsumerdiep.

Obergum church is situated at Kerkpad 14 in Winsum (coordinates: $53^{\circ} 20^{\prime} 0.75^{\prime \prime} \mathrm{N}$, $6^{\circ} 30^{\prime} 49.48^{\prime \prime} \mathrm{E}$ ). The Romanic church with a Gothic apse is located on a mound to keep the church dry during floods, was built in the 13th Century and originally consecrated to Saint Nicholas. Later, in the 15th Century the church was extended, the tower and clock were added in the 17th Century. Nowadays, the building is no longer visible from the street because houses and other buildings have enclosed it. On 27 September 1972, church and interior were listed for its national importance and registered as monument 39042.

In 1970, Obergums' church, which was in a bad technical condition, was the first church to be restored by SOGK. In this period the energy system was installed, since then no other major restoration has taken place.

Building and energy systems: Obergums' church is a middle-sized church (heated surface $90 \mathrm{~m}^{2}$; heated volume $567 \mathrm{~m}^{3}$ ); the exterior is (uninsulated) brickwork masonry (figure 4a) and the interior is an old form of plaster. The hood construction above the attic consists of a uninsulated roof with roof tiles. The tower is also made of bricks and finished in a two waters roof (in contrast with the little towers with spires of the other three churches.) The windows have many different sizes and styles, ranging from very small ones to big arched windows. All windows are provided with single glass. The entrance to the church is by a little lobby in the South side of the tower, the tower itself is in the place of the narthex. 
In the interior, it is a simple church, highly symmetrical. The (uninsulated) floor is decorated with clay tiles. The cabinet organ is built by Hendrikus Hermanus Hess in 1775. After diverse relocations (Gouda, Terhorne) the organ was replaced in Obergum in 1971 (figure 4b). Besides an historic pulpit (1789), removable chairs are places in the church hall (figure 4c). The wooden ceiling between the church hall and attic is uninsulated.

Daily use: The church is used very often for diverse activities, such as concerts, music festivals, social events, and religious services (Christmas) and special services (marriage, funeral). During the year about 50 activities take place with the average duration of four hours up to two or three days. Activities attracts (on average) about 20 up to 120 visitors.

Energy systems and figures: The average electricity use $(1.350 \mathrm{kWh})$ is the result of artificial lighting (and additional lighting for events), and diverse devices. The average use of natural gas (2.100 $\mathrm{m}^{3}$ ) is the result of the heating system. A gas boiler in the attic provides heat (via uninsulated pipes) for plate convectors which are placed along the wall. The basic temperature (no activities) is set on $12^{\circ} \mathrm{C}$ and during activities increased to $18^{\circ} \mathrm{C}$. The pre-heating time is at least one hours in advance.

\subsection{SUMMARY}

The case study description is used as background information, a status quo regarding buildings materials, heating systems and use of each church. As we see in Table 2, hardly any (physical) energy efficiency measures are applied in the churches of Nieuw Scheemda, Lettelbert and Obergum, such as isolation. Only in Leegkerks' church some measures have been applied such as insulation (ceiling, floor) and draught lobbies. Also we find that each church is used with different intensities and the uses are varied: the type of activities and the frequency of use ranges from five times a year to several times a week. Also, we find that the heating management in the churches is divers: different basic and activity temperatures (even no heating in winter period at all), and different pre-heating times before an event; ranged from 1 up to 12 hours in advance. Together with the variety in the buildings heating surface (between $90-177 \mathrm{~m}^{2}$ ) and volume (between $497-1108 \mathrm{~m}^{3}$ ), this results in diverse average yearly energy use: electricity use between $785-3727 \mathrm{kWh}$ and use of natural gas between $678-2803 \mathrm{~m}^{3}$.

Table 2: Background of the case study buildings.

\begin{tabular}{|c|c|c|c|c|}
\hline & Nieuw Scheemda & Leegkerk & Lettelbert & Obergum \\
\hline Exists since & $17^{\text {th }}$ century & $14^{\text {th }}$ century & $13^{\text {th }}$ century & $13^{\text {th }}$ century \\
\hline $\begin{array}{c}\text { Architectural } \\
\text { style }\end{array}$ & Late Gothic & Romanic & Romanic & $\begin{array}{c}\text { Romanic and } \\
\text { Gothic }\end{array}$ \\
\hline Owned by SOGK & 1981 & 1970 & 1977 & 1970 \\
\hline
\end{tabular}




\begin{tabular}{|c|c|c|c|c|}
\hline $\begin{array}{l}\text { Building } \\
\text { materials }\end{array}$ & $\begin{array}{l}\text { Masonry walls, } \\
\text { single glass, tile } \\
\text { floor, wooden } \\
\text { ceiling, attic, roof } \\
\text { tiles } \\
\end{array}$ & $\begin{array}{l}\text { Masonry walls, single } \\
\text { glass, concrete } \\
\text { (insulated) floor, } \\
\text { wooden (insulated) } \\
\text { ceiling, attic, roof tiles }\end{array}$ & $\begin{array}{l}\text { Masonry walls, } \\
\text { single glass, clay } \\
\text { floor, wooden } \\
\text { ceiling, attic, roof } \\
\text { tiles } \\
\end{array}$ & $\begin{array}{l}\text { Masonry walls, } \\
\text { stained glass, clay } \\
\text { tile floor, wooden } \\
\text { ceiling, attic, roof } \\
\text { tiles } \\
\end{array}$ \\
\hline $\begin{array}{l}\text { Heated surface } \\
\qquad\left(\mathrm{m}^{2}\right)\end{array}$ & 148 & 177 & 95 & 90 \\
\hline $\begin{array}{l}\text { Heated volume } \\
\left(\mathrm{m}^{3}\right) \text {-attic excl. }\end{array}$ & 976 & 1108 & 497 & 567 \\
\hline Daily use & $\begin{array}{c}\text { Concerts, } \\
\text { Religious service } \\
\text { (Christmas) }\end{array}$ & $\begin{array}{l}\text { Events of all kind, } \\
\text { including visiting on } \\
\text { Sunday }\end{array}$ & $\begin{array}{c}\text { Icon painting, divers } \\
\text { events, religious } \\
\text { services } \\
\end{array}$ & Events of all kind \\
\hline $\begin{array}{c}\text { Frequency } \\
\text { (times/year) }\end{array}$ & 5 & Very often & $3-10$ & 50 \\
\hline $\begin{array}{l}\text { Duration } \\
\text { (hours) }\end{array}$ & $1,5-2$ & 2 & - & 4 (up to 2-3 days) \\
\hline $\begin{array}{l}\text { Visitors (per } \\
\text { activity/day) }\end{array}$ & $50-70$ & Average 30 (up to 90) & 15 & $\begin{array}{c}\text { Average } 20 \text { (op to } \\
120)\end{array}$ \\
\hline $\begin{array}{c}\text { Electricity (year - } \\
\text { kWh), average } \\
\text { 2009-2012 }\end{array}$ & 954 & $3.727 *$ & 785 & 1.350 \\
\hline Lighting & $\begin{array}{l}\text { Night: artificial } \\
\text { lighting }\end{array}$ & $\begin{array}{l}\text { Day \& night: artificial } \\
\text { light necessary }\end{array}$ & Artificial lighting & $\begin{array}{c}8 \text { lamps; usually } \\
\text { additional lighting } \\
\text { for events (day \& } \\
\text { night) }\end{array}$ \\
\hline $\begin{array}{c}\text { Natural gas (year } \\
-m^{3} \text { ), average } \\
\text { 2009-2012 }\end{array}$ & 2.069 & $2.803^{*}$ & 678 & 2.100 \\
\hline *2012-2017 & & & & \\
\hline
\end{tabular}

Gas boiler (attic), uninsulated pipes, Gas boiler (attic), Gas stove (centre of convectors uninsulated pipes, the nave), electric (lobby) and floor heating and (in radiators convectors $+\quad$ apse area) convectors. (classroom).

Gas boiler (attic), uninsulated pipes (transport), convectors heated pipework 
underneath pews

(nave).

\begin{tabular}{ccccc}
\hline $\begin{array}{c}\text { Basic temperature } \\
\text { (no activities) }\end{array}$ & $\begin{array}{c}\text { During winter } \\
\text { months the } \\
\text { system conserves } \\
\mathrm{a} 10^{\circ} \mathrm{C}\end{array}$ & $10^{\circ} \mathrm{C}$ & $\begin{array}{c}\text { During winter } \\
\text { months the system } \\
\text { conserves a } 12^{\circ} \mathrm{C}\end{array}$ & $\begin{array}{c}\text { maintenance } \\
\text { temperature of } 12 \\
{ }^{\circ} \mathrm{C}\end{array}$ \\
\hline $\begin{array}{c}\text { Temperature high } \\
\text { (activities) }\end{array}$ & $18^{\circ} \mathrm{C}$ & $20^{\circ} \mathrm{C}$ & $\begin{array}{c}18^{\circ} \mathrm{C} \text { (painting } \\
\text { class) }\end{array}$ & $18^{\circ} \mathrm{C}$ \\
\hline Pre-heating time & $\begin{array}{c}12 \text { hours in } \\
\text { advance }\end{array}$ & $\begin{array}{c}\text { At least } 4 \text { hours in } \\
\text { advance }\end{array}$ & $\begin{array}{c}\text { Electric radiators } 1 \\
\text { hour in advance }\end{array}$ & $\begin{array}{c}\text { At least } 1 \text { hour in } \\
\text { advance }\end{array}$
\end{tabular}

\section{RESULTS}

In this chapter we present the findings from the questionnaire and interviews, categorised into three topics. First, we have evaluated the experience of thermal comfort with the interviewees. This provides a background regarding proposals of technologies and interventions to improve comfort. In the second phase we asked the respondents to give predefined and open-ended values to the churches, thus creating a layperson valuation. Finally, the respondents evaluated energy retrofit measures. How these aspects might influence each other is discussed in the next chapter Discussion.

We find that laypersons values and perceptions of thermal comfort versus energy efficiency, can help to consider which buildings need to be retrofitted and in what degree. Heavy investments in energy efficiency of buildings, which are used rarely are not well-spent. Preferably, a building should generate the income to recover the energy investments, or at least to contribute a real benefit to the community. On the other hand, some of the most efficient measures to improve energy efficiency and thermal comfort may be against conservation policies or against users' attitudes and values. In this respect, it is important to note that community values should be considered carefully, as those values are the most relevant characteristics that a listed structure can have, since they provide the reasons for its use and preservation.

Although Nieuw Scheemda has relatively better heating technologies than Lettelbert, its energy use appears to be relatively high, probably due to its size, even when taking into account that it is used more sporadic than Lettelbert. The most efficient is of course Leegkerk as a result of the recent intervention. The energy consumption in Leegkerk is the highest, but this is justified by its high usage frequency. The same observation applies to Obergum, which is being used only 50 times a year but is consuming around half of the energy of Leegkerk. 


\subsection{EVALUATION OF EXPERIENCED THERMAL COMFORT}

An evaluation of the experienced thermal comfort is a preliminary step to allow respondents to reflect on the possibilities to improve the comfort conditions and the energy efficiency of the churches.

In the group interviews, thermal comfort was discussed (Table 3). Here we compare and contrast the four cases on differences between respondents, behavioural aspects, such as wearing warm clothing, specific indications of draughts and their relation to the building physics.

Table 3: Thermal comfort

\begin{tabular}{|c|c|c|c|c|}
\hline & N. Scheemda & Leegkerk & Lettelbert & Obergum \\
\hline \multirow[t]{2}{*}{ Winter period } & Acceptable & Acceptable & Unacceptable (2) & Unacceptable \\
\hline & & & Acceptable (2) & \\
\hline \multirow[t]{4}{*}{ Perception } & Warm (2) & Neutral & Neutral (1) & Little cold \\
\hline & Neutral (1) & & Little cold (1) & \\
\hline & & & Cold (1) & \\
\hline & & & Very cold (1) & \\
\hline \multirow{3}{*}{$\begin{array}{l}\text { After } 30 \\
\text { minutes }\end{array}$} & Id. & Little cold & Little cold (1) & Little cold \\
\hline & & & Cold (2) & \\
\hline & & & Very cold (1) & \\
\hline Specific areas & $\begin{array}{l}\text { Gallery } \\
\text { warmer }\end{array}$ & $\begin{array}{l}\text { Lower area } \\
\text { warmer } \\
\text { (radiant floor?) }\end{array}$ & $\begin{array}{c}\text { Acceptable in } \\
\text { classroom, } \\
\text { unacceptable in church } \\
\text { area }\end{array}$ & \\
\hline Clothing & $\begin{array}{c}\text { Heavy winter } \\
\text { clothes (1) }\end{array}$ & Normal & Heavy winter clothes & \\
\hline Summer period & Acceptable & Acceptable & Acceptable & Unacceptable \\
\hline \multirow[t]{2}{*}{ Perception } & Warm (1) & Little cold & Neutral & Neutral \\
\hline & Neutral (2) & & & \\
\hline $\begin{array}{l}\text { After } 30 \\
\text { minutes }\end{array}$ & Id. & Little cold & Neutral & Little cold \\
\hline
\end{tabular}




\begin{tabular}{ccccc} 
Draughts & $\begin{array}{c}\text { From North } \\
\text { windows }\end{array}$ & $\begin{array}{c}\text { From both } \\
\text { doors and } \\
\text { windows }\end{array}$ & $\begin{array}{c}\text { Cold draughts in } \\
\text { winter }\end{array}$ & \\
\hline $\begin{array}{c}\text { Lighting } \\
\text { during } \\
\text { daytime? }\end{array}$ & Acceptable & $\begin{array}{c}\text { Artificial light } \\
\text { necessary }\end{array}$ & Enough daylighting & \\
\hline Air quality & Satisfying & Satisfying & Bad \\
\hline Acoustics & Acceptable to & & Bad (echo)
\end{tabular}

Experienced thermal comfort: In the case of Lettelbert, the respondents agreed that during winter they have to wear heavy clothes and have all heating devices turned on to keep warm, although the respondents differed in their assessment. In Leegkerk on the contrary, respondents recognised that during a big event in winter it would be necessary to remove the heavier clothes with which they arrived to the church. In the case of Nieuw Scheemda they reported that the conditions are acceptable and no further action is needed, although this may be also aligned with the perception that all churches are necessarily cold. On the other hand Obergum respondent reported clearly that the thermal comfort is deficient, which ties in with the deplorable state of the thermal efficiency of the building, full of thermal bridges.

Other topics: the lighting in the churches was considered acceptable, although in Leegkerk additional artificial lighting was preferred. The air quality was evaluated as satisfying in Leegkerk and Lettelbert, in Obergum it was bad. In Leegkerk the acoustics were experienced as acceptable to good. In Obergum as bad due to echoing.

Summarizing thermal comfort, the churches in Nieuw Scheemda, Lettelbert and Leegkerk were considered acceptable. Nevertheless, in Nieuw Scheemda and Lettelbert it was deemed necessary to wear heavy clothing in winter; while in Leegkerk warm clothing was needed all year round. In Obergum, the thermal comfort level was considered insufficient. Judgment was adapted in some cases by taking the age of the building into account.

\subsection{STAKEHOLDERS' VALUATION}

In this section, we give an overview of the values that our interviewees ascribed to their buildings We scaled the responses on a five-point scale: absolutely unimportant (--), unimportant (-), somewhat important $(+/-)$, important $(+)$, very important $(++)$. Based on literature $[3,13]$ we categorized the addressed values into: Age value; Architectural and artistic value; Emotional value; Historic value; Religious value; Political value; Educational value; Community value; Non-use economical value. Architectural and artistic/aesthetical value is split in two separate values. If the value did not come up in the interview this is indicated with ' $x$ '. After an overview of the valuations in Table 4, we describe the results in more detail below per value. 
Table 4: Values

\begin{tabular}{ccccc} 
Values & $\begin{array}{c}\text { Nieuw } \\
\text { Scheemda }\end{array}$ & Leegkerk & Lettelbert & Obergum \\
\hline Age value & $+/-$ & + & ++ & $+/-$ \\
\hline Architectural value & + & $+/-$ & +- & ++ \\
\hline Artistic/ Aesthetical value & - & + & ++ & +- \\
\hline Emotional value & -- & -- & + & $+/-$ \\
\hline Historic value & -- & + & ++ & -- \\
\hline Religious value & ++ & -- & $\mathrm{x}$ & $\mathrm{x}$ \\
\hline Political value & -- & $\mathrm{x}$ & $\mathrm{x}$ & $\mathrm{X}$ \\
\hline Educational value & -- & $\mathrm{X}$ & ++ & ++ \\
\hline Community value & $+/-$ & $+/-$ & ++
\end{tabular}

History and architectural values: The historical values of the church were important to all respondents, which could both relate to the building itself as to certain elements that were deemed especially important. The majority of the respondents are interested in history and consider themselves to be knowledgeable about the history of the church. In some cases, the building was mentioned as a site of important historical events, such as Leegkerk, which had a role in the Eighty Year's War (15681648), fought by the Netherlands against the Spanish Empire. The architectural value of the church was considered not important by the respondents in Lettelbert, whereas the age value was considered very important. In Leegkerk the simplicity of design was mentioned as a special quality. On the other hand, in Nieuw Scheemda the respondents were unaware of the history of the church and considered the aesthetical value of the church as not very important. The value of authenticity was added as an important value in Obergum.

Valuable elements: The churches house several elements which are deemed important. Integral to the building are niches in the apse in Leegkerk. The piscina in Leegkerk and the altar stone in Lettelbert are remembrances of the period before the reformation. In Obergum the cave under the church was especially valued, maybe because of its authenticity. Gravestones in the floor provide memories of people who have lived and died in the community. The pulpit in Lettelbert is valued as a decorated wooden interior item. Other elements include an old bible in Nieuw Scheemda. Some of these elements contribute to other values, such as the peaceful atmosphere, memories of earlier periods or people. 
Atmosphere and memories: The interior of the church is often experienced as peaceful; in one case the atmosphere was considered one of the main qualities. In Nieuw Scheemda respondents stated that the (Christian) religious value of the church was 'very important', (general) spiritual value was put forward quite strongly in the case of Lettelbert. In the other two cases this original value of churches was considered 'not important'. Furthermore, personal memories of the respondents themselves or others in the community were considered important.

Community and economy: Apart from the values in themselves, it is interesting to analyse who these values are for. Some respondents argue that the church fulfils an important role for the community by providing a place for local events. This includes cultural events, such as concerts, but also more commercial activities, such as weddings or funerals. Moreover, the organisation of events is the mainstay of the survival of these churches. Other values are considered important for the public, including tourists, visitors of events, or 'heritage visitors'. The income generated by these activities guarantee the economic sustainability of the buildings, which is one of the notions that guide the interventions of adaptive reuse.

Regarding the economic benefits of the church reactions were mixed. In three cases, the general feeling was that the profits should only provide for the (daily) upkeep of the church. In Lettelbert the respondents envisaged a greater economic contribution of the church, by attracting tourists to the village.

Acoustics: An important characteristic of Nieuw Scheemda is its excellent acoustics, which makes the church attractive for concerts. The organ, by the famous organ builder Arp Schnitger, is probably as valuable as the church itself. The interviewees even state that the church should be demolished, were it not for the good acoustics. On the other hand, in Obergum the church lacks good acoustics, which makes it less attractive for musical events.

Considering registers of valuing, following Heuts and Mol [7], we acknowledge several clusters of valuation, which can be related to actors' interests. For the 'history buff' the historical qualities of the church are its main attraction, including valuable elements. The 'community organizer' is primarily interested in what the church can do, as a meeting point, a place for cultural events, concerts. The 'spiritualist' is looking for religious or spiritual inspiration and values the atmosphere of peace and quiet. On a personal level this is related to personal memories or religious nostalgia. Economic benefit wasn't a very prominent motivator, only as far as the benefits are necessary for the upkeep of the building.

\subsection{ENERGY RETROFIT PROPOSALS}

In the interviews photos were presented of energy retrofit interventions, interviewees were asked to give their opinion on the implementation of these interventions for their own church, The results, see Table 5, are described below in more detail.

Table 5: Energy retrofit proposals 


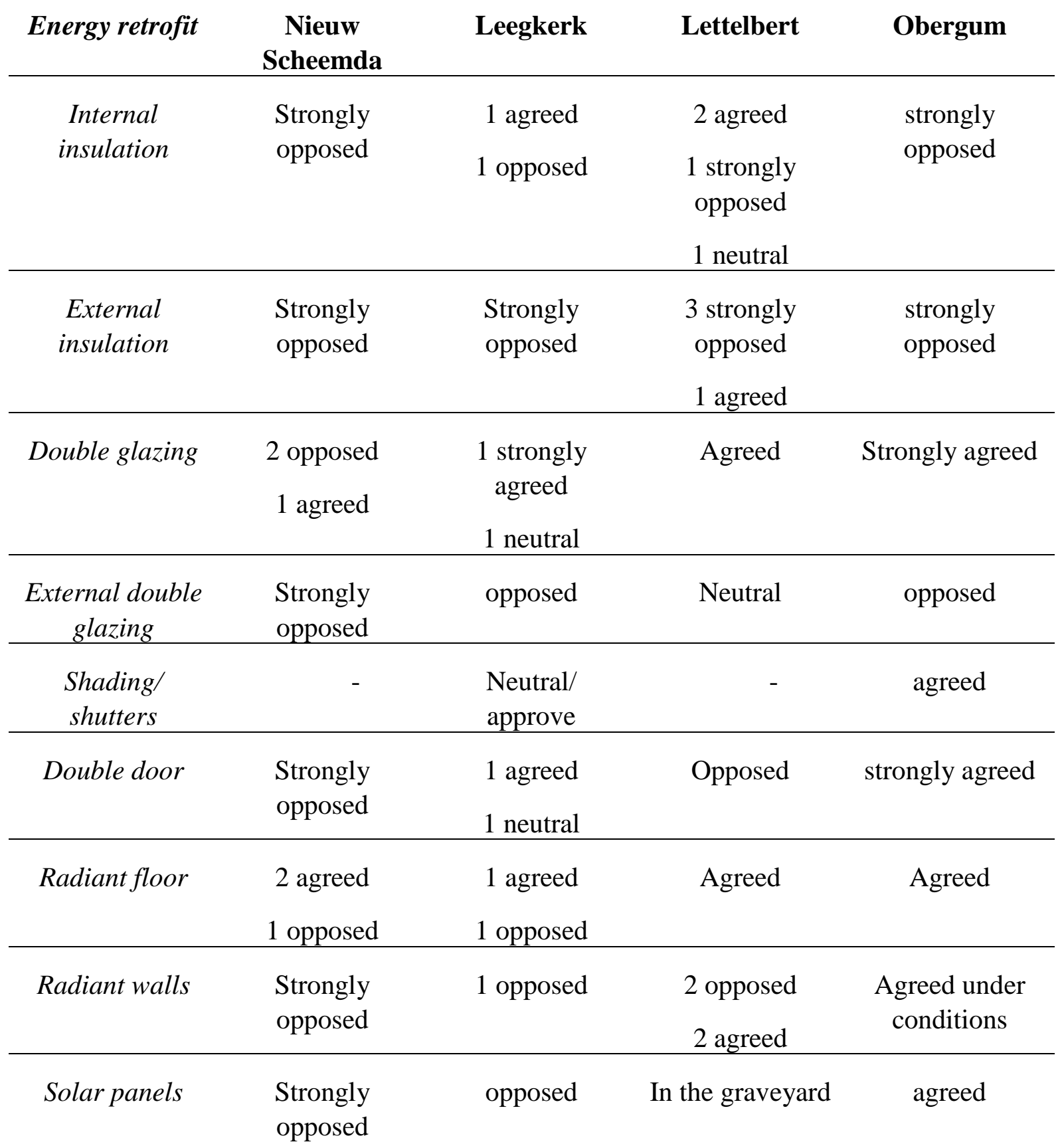

Internal and external insulation. Insulation attracted mixed reactions, but overall both internal and external insulation was strongly opposed by almost all respondents.

Glazing and doors. Double glazing was strongly opposed by the majority of respondents. Only in Lettelbert respondents agreed to double glazing. In Obergum the respondent agreed with floor heating, internal double glazing, screening, shutters, and the glass double lobby. Overall, the reactions to the 
internal double door and lobby varied considerably, from strong opposition to strong agreement. This could be related to the authenticity of the interior and the impact this intervention would have.

Heating systems. Partition heating was primarily opposed, while floor heating was the least controversial intervention.

Solar panels. The reaction to solar panels varied from strong opposition to agreement, with respondents in Lettelbert suggesting the removal of gravestones to allow for the placing of PV panels in the graveyard. Only Obergum agreed with PV panels on the roof.

Many reactions of the respondents were highly negative regarding most interventions. In Nieuw Scheemda there was powerful opposition against almost all the possibilities presented, although internal double glazing and floor heating had some agreement. In Leegkerk none of the interventions could count on unanimous agreement.

\subsection{COMPARISON OF CASE STUDY BUILDINGS}

In this paragraph the results are compared per case study building, since the experienced thermal comfort and laypersons valuation might affect the evaluation of energy retrofit proposals. We finish this paragraph with an overall cross-case comparison.

\subsubsection{Nieuw Scheemda}

The interviewees in Nieuw Scheemda are committed to conserve and use this building under two principles: acoustics and religious nostalgia. Ironically the first one is the main reason to negate all possible interventions in the building, while the latter was expressed as the factor that makes the church useless. The informants were of the opinion that investments were not merited, because is not used as a church anymore. They stated that if not for the acoustics the building should be demolished. This seems contradictory with their defence of the structure against any improvement. Participants expressed no interest in energy efficiency, considering that the actual systems work well. Perhaps energy retrofit measures are not felt as an urgent topic, due to relative good experiences with thermal comfort. Finally, they do not value the graveyard at all. When proposed the installation of solar panels on the roof, they instead suggested the removal of the gravestones outside to give room for the panels.

In this case we can see an indirect religious value; by denying an intervention on the basis that the church is no longer a place for worship, they are expressing a strong attachment to the original function of the building. Therefore, the religious value takes a dominant position next to the acoustic one. Ideally for the respondents, the church should be used by in their present context and keep being used as a church, although the societal and cultural conditions of the population - atheism and laicism preponderant in the majority of inhabitants - no longer allow the religious original use to return. 


\subsubsection{Leegkerk}

The respondents at Leegkerk are pensioners with a higher educational level; they showed much more environmental consciousness in their reaction to the energy-efficiency proposals. On the other hand, they do not see a real need for improving the energy efficiency of the building that could have a large impact on aesthetics.. While they recognized the existence of some thermal bridges, they would prefer more discreet interventions. For the summer conditions, the feeling of cold inside the church seems to be a major concern; respondents expressed the need to use long sleeves while being inside in summer. They would accept improvements in the thermal bridges and the heating system.

\subsubsection{Lettelbert}

It is true that the building is in general efficient in thermal and energy means, although some easy improvements can be made by treating some thermal bridges. The recent intervention and the kind state of the interiors would discourage some from improvements. In this church values played a lesser role but authenticity and the unwillingness to see more modifications appear to be an important element.

Lettelbert church presents a grave problem of outdated technology, it has been renovated in 1985 without any improvements in energy-efficiency. The church is valued as a spiritual place, well suited to the icon-painting classes. During winter interviewees have to struggle with the two heating devices inside the classroom, while trying to avoid the cold coming in from the church. The teacher expressed the desire to transform the whole church into a classroom, and to dispose of the pews and benches. He even desires to create and install an iconostasis with the works of the students, this in order to give a greater atmosphere of orthodox spirituality during the lessons. For those conversions, he would like to receive the support of the local committee, but acknowledges that the energy retrofitting of the church is probably a higher priority.

This is one of the two churches much more used, and it actually has in some degree returned to the original use, the religious inspiration, granted by the icon painting classes. Also has some profit due to the foreign visitors that go to take the icon courses, some from other countries and that are accommodated by the permanent residents for a fee. This church generates some income while still is a relevant place for the small community. Improving the thermal and energy efficiency would get immediate benefits and the respondents attitudes are not completely against some improvements.

\subsubsection{Obergum}

For Obergum, the intervention for energy-efficiency is already programmed and it is also highly needed. Present conditions are uncomfortable and the heating system can hardly cope with the heat demand. Floor heating is positively regarded, as the present floor is not authentic. Preservation of the historic atmosphere is seen as very important.

The historical photos of the church showed that the internal plaster dates back to the restoration of 1969, however, the respondent believes that the plaster is original and therefore should not be touched. 
Apparently, the church has a good potential to generate income; it is located in an important town in the region with easy access from the capital city of Groningen.

\subsubsection{Conclusions cross-case comparison}

Comparing the assessments of comfort with the attributed values, we find that although the proposed energy retrofit measures would reduce the energy expenditure as well as contribute to more comfort, stakeholders were generally opposed to interventions that would interfere with the physical appearance of the churches. Floor heating was the most accepted intervention, considering that the floors do not greatly contribute to the values outlined in Table 4. Other interventions like wall-heating or external glazing received overwhelming opposition, even when these would greatly contribute to the thermal comfort performance of a buildings. Here, conflicts between energy efficiency and heritage conservation becomes evident. In the end, in a process of conservation the users and local stakeholders would be the most affected by the interventions planned. For this reason, the values outlined become important when we look at for example the value of 'community value', which was pointed as one of the most relevant for the participants. This will be perhaps the church that would benefit the most from an intervention, both in thermal efficiency and energy efficiency; the chance to increase its use a comfortable public venue is on the way to guarantee its economic sustainability.

\section{DISCUSSION}

We investigated laypersons' values regarding historic churches in Groningen, their experience of comfort and their views of the appropriateness of energy measures. Will differences between experts and non-experts fade away, as Janssen et al [9] argues? We found that traditional architectural-historical values did play a role in laypersons ' valuations, especially specific historic elements and historic value were mentioned. The valuation of the architecture ranged from valuing simplicity to considering the building as unimportant safe for its acoustics. In Obergum, the informant defended the 'atmosphere of authenticity' and rejected interventions which might compromise the walls. Considering registers of valuing, as brought forward by Heuts and Mol [7], we identified several clusters of valuation, which can be related to actors' interests. For the 'history buff' the historical qualities of the church are its main attraction, including valuable elements. The 'community organizer' is primarily interested in what the church can do, as a meeting point, a place for cultural events, concerts. The 'spiritualist' is looking for religious or spiritual inspiration and values the atmosphere of peace and quiet. On a personal level, this is related to personal memories or religious nostalgia. Economic benefit was not a very prominent motivator in itself, only as far as the benefits are necessary for the upkeep of the building. Registers of values could also be related to the educational background, environmental or community values of respondents.

In this respect, the position of the interviewees seemed of importance. In Nieuw Scheemda and Obergum we have the impression that they were following a group agenda, instead of expressing personal values. Environmental consciousness was related to the level of education, with higher 
education leading to a greater interest in saving energy. Specific values can be related to a community perspective and the role the church plays in this community. The church in Lettelbert as painting school has become an important element in community identity and emotions. Also in the other cases, the church is integrated in local activities and is a highly valued part of the local network. These findings are also in keeping with the Heritage-as-a-spatial-vector-approach.

The present state of the building and the frequency of use obviously influence the need for energy retrofit. Therefore, Lettelbert and Obergum require the most attention for thermal upgrading. In the case of Nieuw Scheemda respondents were very perceptive of the economic costs of the proposed interventions, even though the committee itself does not have to pay for restoration work. This probably also relates to the very low use frequency of five times a year. In their view, the church did not merit high investments in energy retrofit. In Leegkerk, respondents preferred discreet (largely invisible) energy measures because of their valuation of the historical character of the church, combined with the already positive results of the latest renovation. When we aim to seriously involve the way people feel and care about their building, as Fouseki and Cassar propose, feelings of (dis)comfort and opinions about the spending of public resources should be taken into account. On the other hand, laypersons' can also include traditional architectural-historical values in their assessment of the propriety of energy measures. In that case, experts and non-experts agree.

More research needs to be done into laypersons' values, especially regarding values of the wider community. Our findings do not diminish the importance of experts' values, but adds to them another layer, including social and environmental values.

We can identify some interventions that may be needed from an energy point of view, but not desirable for the community. Lettelbert is one of the most frequently used churches, but it is very uncomfortable and inefficient in heating technologies. However, its yearly energy use is low. An energy intervention in Lettelbert church would improve the conditions for the icon painting class, however, the respondents highly value the church but reject most energy interventions. On the other hand, Leegkerk is in this sense an example of efficiency, because it has reached economic sustainability, providing an important source of income for the community and to SOGK.

We conclude that for a more balanced approach, laypersons' valuations of historical buildings should be further investigated in heritage studies. In particular, community values and comfort needs should be more fully addressed in value assessments. Heritage-as-a-vector for development requires professionals involved in conservation to include community attitudes and values into heritage valuation, and integrate laypersons' values in design and decision-making. Only by taking the community as one of the main references for decisions and policies, heritage truly becomes a factor and a vector for development.

\section{REFERENCES}


[1] G. Ashworth, "Preservation, Conservation and Heritage: Approaches to the Past in the Present through the Built Environment," Asian Anthropology, vol. 10, no. 1, pp. 1-18, 2011.

[2] N. Walter, "From values to narrative: a new foundation for the conservation of historic buildings," (in English), International Journal of Heritage Studies, vol. 20, no. 6, pp. 634-650, Jul 2014.

[3] M. de la Torre and R. Mason, "Introduction," in Assessing the Values of Cultural Heritage. Research Report., M. d. l. Torre, Ed. Los Angeles, CA.: The Getty Conservation Institute, 2002, pp. 3-4.

[4] L. H. Fredheim and M. Khalaf, "The significance of values: heritage value typologies reexamined," International Journal of Heritage Studies, vol. 22, no. 6, pp. 466-481, 2016.

[5] C.-F. Helgesson and F. Muniesa, "For what it's worth: An introduction to Valuation Studies," Valuation Studies, vol. 1, no. 1, pp. 1-10, 2013.

[6] F. Vatin, "Valuation as Evaluating and Valorizing," Valuation Studies, vol. 1, no. 1, pp. 31-50, 2013.

[7] F. Heuts and A. Mol, "What Is a Good Tomato? A Case of Valuing in Practice," Valuation Studies, vol. 1, no. 2, pp. 125-146, 2013.

[8] J. Janssen, E. Luiten, H. Renes, and J. Rouwendal, "Heritage planning and spatial development in the Netherlands: changing policies and perspectives," International Journal of Heritage Studies, vol. 20, no. 1, pp. 1-21, 2014.

[9] J. Janssen, E. Luiten, H. Renes, and E. Stegmeijer, "Heritage as sector, factor and vector: conceptualizing the shifting relationship between heritage management and spatial planning," (in English), European Planning Studies, vol. 25, no. 9, pp. 1654-1672, 2017.

[10] P. P. Witsen, Character Sketches; National Heritage and Spatial Development Research Agenda; Part 1 Research Agenda (The Heritage and Spatial Development Research Agenda). Amersfoort: Netwerk Erfgoed en Ruimte, 2014.

[11] K. Fouseki and M. Cassar, "Editorial: Energy Efficiency in Heritage Buildings - Future Challenges and Research Needs," The Historic Environemnt, vol. 5, no. 2, pp. 95-100, 2014.

[12] R. Mason, "Assessing Values in Conservation Planning: Methodological Issues and Choices," in Assessing the Values of Cultural Heritage. Research Report., M. d. l. Torre, Ed. Los Angeles, CA.: The Getty Conservation Institute, 2002, pp. 5-30.

[13] P. Drury, "Conservation An Evolving Concept," no. 2 june 2015, Accessed on: 2 june 2015Web Article. Available: http://www.buildingconservation.com/

[14] R. K. Yin, Case study research : design and methods, Fifth edition.. ed. Los Angeles : SAGE, 2014. 
[15] H. R. Bernard, Research Methods in Anthropology: Qualitative and Quantitative Approaches, 4th ed. Oxford: Altamira Press, 2006, p. 803.

[16] N. K. Denzin and Y. S. Lincoln, Handbook of Qualitative Research. Thoisand Oaks, California: Sage Publications, 2000.

[17] E. Colmenero-Acevedo, "Identifying Sociocultural Values of Environmental Sustainability within Architectural Heritage," Architectuur- en stedenbouwgeschiedenis - Master Master Thesis, Kunst- en Cultuurwetenschappen, Rijksuniversiteit Groningen, Groningen, 2015.

[18] Images by Maarten Vieveen, 10-10-2013

[19] SOGK - image archives 